\title{
W poszukiwaniu nowych mierników zadłużenia samorządowego. Analiza przypadku na przykładzie okresu spłaty gmin województwa kujawsko- pomorskiego w latach 2002-2015
}

Looking for new measures of local government debt. Case study of an example of repayment period of communes of Kujawsko-Pomorskie voivodeship in the years 2002-2015

Streszczenie. Dług jednostek samorządu terytorialnego w przeważającej części stanowi sumę zobowiązań zwrotnych zaciągniętych w celu realizacji przedsięwzięć o charakterze inwestycyjnym. Nie dziwi więc, że w literaturze przedmiotu zadłużenie samorządowe przedstawiane jest głównie jako dobre, opłacalne czy też konstruktywne. Zaciąganie zobowiązań zwrotnych zawsze wiąże się z możliwością wystąpienia efektów negatywnych, niemniej wydaje się, że często bywają one bagatelizowane. W licznych publikacjach zarówno naukowych, jak i publicystycznych zadłużenie polskich samorządów oceniane jest przede wszystkim przez pryzmat jego stosunku do osiąganych dochodów. Konieczne jest jednak poszukiwanie mierników oraz źródeł danych pozwalających na spojrzenie na ten dług 
z nowych perspektyw. Celem niniejszego opracowania jest zaprezentowanie wyników badań przeprowadzonych w gminach województwa kujawsko-pomorskiego z zastosowaniem nowych mierników ich zadłużenia.

Słowa kluczowe: dług publiczny; samorząd terytorialny.

Abstract. The debt of local government units is, to a large extent, the sum of repayment of commitments contracted to carry out investment projects. It is not surprising that in the literature of the subject local government debt is presented mainly as good, profitable or constructive. Commitment to repayment obligations is always associated with the possibility of an occurrence of negative effects which often appear to be underestimated. In numerous scientific and public publications, the indebtedness of the Polish self-governments is assessed first of all by the prism of its relation to earned incomes. However, it is imperative to look for metrics and data sources to look at this debt from new perspectives. The purpose of this study is to present the results of research conducted in the communes of the Kujawsko-Pomorskie voivodeship using new measures of their debt.

Keywords: public debt; local government.

\section{Wprowadzenie}

Dług jednostek samorządu terytorialnego w przeważającej części stanowi sumę zobowiązań zwrotnych zaciągniętych w celu realizacji przedsięwzięć o charakterze inwestycyjnym ${ }^{1}$. Nie dziwi więc, że w literaturze przedmiotu zadłużenie samorządowe przedstawiane jest głównie jako dobre $^{2}$, opłacalne ${ }^{3}$ czy też konstruktywne ${ }^{4}$. Zaciąganie zobowiązań zwrot-

1 Zob. m.in.: D. Jurewicz, Dług samorzq̨du - bodziec czy bariera absorpcji środków europejskich?, „Ruch Prawniczy, Ekonomiczny i Socjologiczny” 2016, nr 2, s. 231249; J. Czempas, Skłonność jednostek samorzq̨du terytorialnego do inwestowania. Ujęcie ilościowe na przykładzie miast na prawach powiatu województwa ślq̨skiego, Katowice 2013; K.S. Cichocki, Zarzq̨dzanie finansami i długiem samorzqdu terytorialnego w perspektywie wieloletniej, Warszawa 2013.

2 M. Poniatowicz, Dobry dług versus zły dług, czyli o specyfice zadłużenia sektora samorzq̨dowego, [w:] J. Szołno-Koguc, A. Pomorska (red.), Ekonomiczne i prawne uwarunkowania i bariery redukcji deficytu i długu publicznego, Warszawa 2011, s. 490.

3 A. Borodo, Kredyty, pożyczki i obligacje jako źródło finansowania zadań jednostek samorzqdu terytorialnego, [w:] A. Borodo (red.), Samorzq̨d terytorialny a banki, Toruń 2002, s. 10-11. 
nych zawsze wiąże się z możliwością wystąpienia efektów negatywnych, niemniej wydaje się, że często bywają one bagatelizowane.

W licznych publikacjach zarówno naukowych, jak i publicystycznych zadłużenie polskich samorządów oceniane jest przede wszystkim przez pryzmat jego stosunku do osiąganych dochodów. Wraz ze znaczną zmianą jego poziomu zmienia się również natężenie zjawisk z nim związanych. Konieczne jest więc poszukiwanie mierników oraz źródeł danych pozwalających na spojrzenie na dług z nowych perspektyw. Pomimo tego, że zagadnienia zadłużenia publicznego (w tym samorządowego) są przedmiotem licznych publikacji, na tym polu badawczym istnieją pokaźne luki. Problemy związane ze zdarzeniami gospodarczymi, w tym w szczególności z zadłużeniem, muszą być rozpatrywane z różnej perspektywy czasowej. Wydłużenie tej perspektywy powoduje, że zmieniają się otaczające nas okoliczności - jedne słabną, inne nasilają się, pojawiają się również zupełnie nowe. Przykładem nowych, słabo zidentyfikowanych i opisanych w literaturze przedmiotu aspektów związanych z zadłużeniem samorządowym jest zjawisko jego refinansowania, popularnie zwanego rolowaniem ${ }^{5}$.

O wyborze problematyki okresów spłaty zadłużenia samorządowego zdecydowały z jednej strony przeświadczenie istnienia znacznych luk na tym polu badawczym, z drugiej obawa negatywnych konsekwencji, jakie może spowodować pomijanie tych zagadnień. Zasadniczym celem niniejszego opracowania jest zaprezentowanie wyników badań przeprowadzonych przez autora w gminach województwa kujawsko-pomorskiego z zastosowaniem mierników wzorowanych na tych używanych do analizowania zadłużenia na szczeblu centralnym. Zdecydowanie aplikacyjny charakter opracowania oraz ograniczony rozmiar miały kluczowy wpływ na jego strukturę. Po krótkim omówieniu mierników, jakie zostały wykorzystane w badaniach, zaprezentowany został zakres przedmiotowy, podmiotowy

4 M. Zioło, Zadłużenie gmin - przesłanka czy ograniczenie w procesie kreowania ich rozwoju? Analiza przypadku na przykładzie gmin województwa zachodniopomorskiego, [w:] J. Szołno-Koguc, A. Pomorska (red.), Ekonomiczne i prawne uwarunkowania i bariery redukcji deficytu i długu publicznego, Warszawa 2011, s. 474-476.

5 Więcej na ten temat: D. Jurewicz, Refinansowanie długu polskich gmin, tekst w druku, planowany do opublikowania w „Ruch Prawniczy, Ekonomiczny i Socjologiczny” 2017 , nr 2. 
oraz czasowy przeprowadzonych badań. Następnie, w sposób syntetyczny, przedstawione zostały wyniki badań oraz ich interpretacja. Opracowanie kończy zaś podsumowanie zawierające najważniejsze wnioski.

Mimo że opracowanie ma zakres regionalny, autor ma nadzieję, że przez pryzmat tego regionalnego studium przypadku, osadzonego na szerszym tle porównawczym, przedstawione wyniki badań mogą stanowić przyczynek do dalszej dyskusji nad rolą zadłużenia jednostek samorządu terytorialnego.

\section{Okres spłaty zadłużenia nadwyżką operacyjną}

Jednym z ryzyk związanych z długiem publicznym na szczeblu centralnym jest ryzyko jego refinansowania ${ }^{6}$. Mierzy się je na podstawie średniego okresu wymagalności zobowiązań, stanowiącego wyrażoną w latach średnią długość okresu, po którym zaciągnięty dług jest spłacany. Im okres jest dłuższy, tym wyższe jest ryzyko refinansowania długu. W publikacjach dotyczących zarządzania samorządowym długiem publicznym pośród licznych ryzyk nie wskazuje się jednak ryzyka jego refinansowania $^{7}$. Średni okres wymagalności zobowiązań w wersji wykorzystywanej w odniesieniu do długu na poziomie państwa byłby możliwy do zastosowania w przypadku jednostek samorządu terytorialnego jedynie w sytuacji posiadania szczegółowych danych w zakresie wszystkich umów dotyczących poszczególnych tytułów dłużnych, co nie wydaje się niestety możliwe. Tak rozbudowanych danych nie posiada nawet minister właściwy do spraw finansów publicznych, który jest organem odpowiedzialnym za cały państwowy dług publiczny. Możliwe jest jednak zmodyfikowanie miernika w taki sposób, aby możliwe było wykorzystanie danych będących w obiegu publicznym.

6 T. Uryszek, Ryzyko refinansowania długu Skarbu Państwa w Polsce, „Finanse i Prawo Finansowe” 2014, nr 2, s. 55.

7 M. Poniatowicz, Dług publiczny w systemie finansowym jednostek samorzqdu terytorialnego (na przykładzie miast na prawach powiatu), Białystok 2005, s. 253-259; M. Poniatowicz, J.M. Salachna, D. Perło, Efektywne zarzqdzanie długiem w jednostce samorzqdu terytorialnego, Warszawa 2010, s. 118-148. 
Propozycją o bardzo uniwersalnym zakresie możliwości wykorzystania jest okres spłaty zadłużenia nadwyżką operacyjną. Nadwyżka operacyjna to jeden z najważniejszych wyznaczników oceny sytuacji finansowej samorządów. Stanowi ona różnicę między zrealizowanymi dochodami bieżącymi a wydatkami bieżącymi i wskazuje, jak wiele środków finansowych generowanych przez dany samorząd pozostaje po sfinansowaniu jego bieżącego funkcjonowania. Uchwalona w 2009 r. ustawa o finansach publicznych ${ }^{8}$ znacząco podniosła jej znaczenie w sensie formalnym - to od tej wielkości w największym stopniu zależy dopuszczalny poziom zadłużenia samorządów. W praktyce zaś to z nadwyżki operacyjnej samorządy mogą finansować działalność inwestycyjną lub dokonywać spłaty posiadanego zadłużenia.

Okres spłaty zadłużenia nadwyżką operacyjną wskazuje, ile czasu, liczonego w latach, zajęłaby jednostce samorządu terytorialnego spłata zadłużenia przy założeniu, że cała wygenerowana przez nią nadwyżka operacyjna zostałaby przeznaczona na spłatę zadłużenia. Aby uzyskać wspomniany okres, należy podzielić posiadane na koniec danego roku zadłużenie przez osiągniętą $\mathrm{w}$ tym roku nadwyżkę operacyjną. Zaprezentowana miara ma charakter uniwersalny i może być zastosowana w odniesieniu zarówno do poszczególnych samorządów, jak i do dowolnych ich grup.

\section{Zakres przeprowadzonych badań}

Podmiotem przeprowadzonych badań empirycznych były gminy województwa kujawsko-pomorskiego, a więc grupa licząca 144 obiekty badawcze, w tym 4 miasta na prawach powiatu, 13 gmin miejskich, 35 gmin miejskowiejskich oraz 92 gminy wiejskie. Charakter pracy i osobiste zainteresowania autora dały możliwość zebrania obszernego materiału badawczego oraz przeprowadzenia analizy w odniesieniu do stosunkowo długiego okresu. Badaniami objęty został bowiem okres od 2002 do 2015 r. W horyzoncie czaso-

8 Ustawa z dnia 27 sierpnia 2009 r. o finansach publicznych (tekst jedn. Dz.U. z 2016 r. poz. 1870 ze zm., dalej: u.f.p.). 
wym, jaki obejmuje praca, szczególnego znaczenia nabierają dwa zjawiska: rosnący poziom długu oraz absorpcja środków europejskich. Przed wspólnotami lokalnymi pojawiły się, z jednej strony, nowe możliwości pozyskania znacznie większej niż wcześniej ilości środków finansowych na realizację przedsięwzięć sprzyjających rozwojowi lokalnemu, z drugiej strony, poważne wyzwania wynikające ze znacznego wzrostu poziomu zadłużenia. Przedmiotem badań były: zadłużenie gmin oraz generowane przez nie nadwyżki operacyjne. Badania zostały przeprowadzone na bogatym, wszechstronnie przeanalizowanym zbiorze informacji. Zgromadzenie oraz zagregowanie niezbędnych danych nie byłoby możliwe bez zastosowania należącego do Ministerstwa Finansów programu informatycznego Bestia, za pośrednictwem którego dane finansowe jednostek samorządu terytorialnego przekazywane są, pod nadzorem regionalnych izb obrachunkowych, do Ministerstwa Finansów.

\section{Wyniki badań}

Jak już wspomniano, zadłużenie polskich samorządów oceniane jest przede wszystkim przez pryzmat jego stosunku do osiąganych dochodów budżetowych. Na wykresie 1 przedstawiono ten stosunek dla wszystkich gmin województwa kujawsko-pomorskiego w latach 2002-2015.

Wykres 1. Zadłużenie gmin województwa kujawsko-pomorskiego jako część zrealizowanych dochodów w latach 2002-2015.

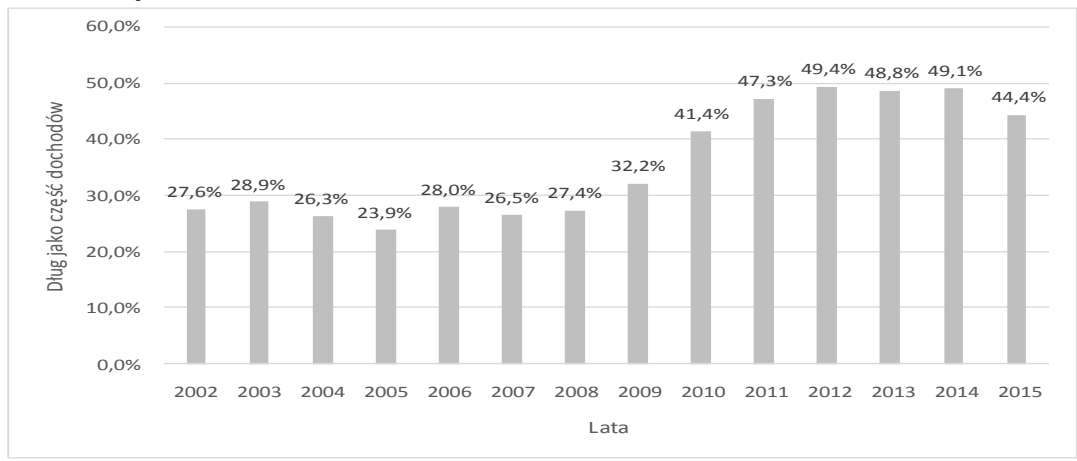

Źródło: obliczenia własne na podstawie sprawozdań budżetowych badanych gmin. 
W okresie objętym analizą nastąpił znaczny wzrost wolumenu zadłużenia gmin województwa kujawsko-pomorskiego, co spowodowane było przede wszystkich zwiększonym wysiłkiem inwestycyjnym związanym z absorpcją środków z budżetu Unii Europejskiej. Analizując to zadłużenie przez pryzmat jego stosunku do zrealizowanych dochodów, stwierdzić należy, że w okresie od 2002 do 2008 r. stosunek ten znajdował się na stabilnym poziomie w zakresie od 23,9\% do 28,9\%. Począwszy od 2008 r. nastąpił wyraźny wzrost trwający do 2012 r., kiedy to wspominany stosunek wzrósł prawie dwukrotnie do poziomu blisko 50\%, po czym ustabilizował się, a w 2015 r. spadł.

Jak już wspomniano we wstępie, konieczne jest poszukiwanie nowych mierników, pozwalających na spojrzenie na kwestie zadłużenia samorządowego również z innych perspektyw. Na wykresie 2 przedstawiono omówiony okres spłaty zadłużenia gmin województwa kujawskopomorskiego w latach 2002-2015.

Wykres 2. Okres spłaty zadłużenia gmin województwa kujawsko-pomorskiego zrealizowanymi nadwyżkami operacyjnymi w latach 2002-2015.

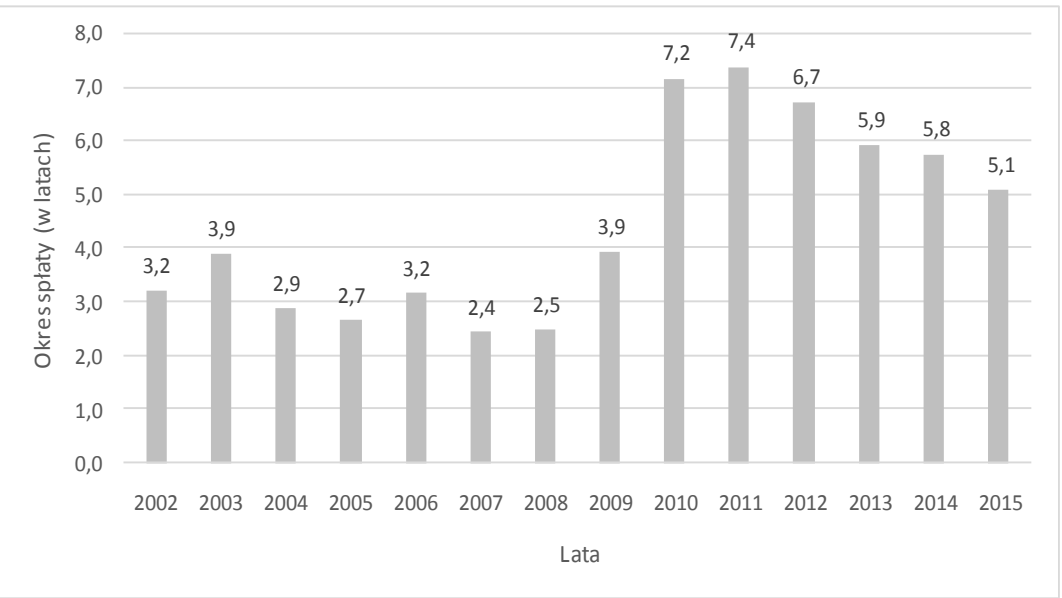

Źródło: obliczenia własne na podstawie sprawozdań budżetowych badanych gmin. 
Zaprezentowane na wykresie 2 dane wskazują, że w analizowanym czasie okres spłaty zobowiązań charakteryzował się znacznie większą zmiennością niż zadłużenie jako część dochodów badanych gmin. Podobnie jak stosunek długu do dochodów okres spłaty był dość stabilny do 2008 r., po czym nastąpił znaczny jego wzrost. Wzrost był jednak bardziej wyraźny, bo aż trzykrotny. Był on efektem wzrostu wolumenu posiadanego zadłużenia połączonego z malejącą tendencją nadwyżek operacyjnych. Po 2010 r. wielkość zadłużenia ustabilizowała się, niemniej wyraźnie rosnąć zaczął poziom generowanych przez badane gminy nadwyżek operacyjnych, co spowodowało spadek okresu spłaty zadłużenia gmin województwa kujawsko-pomorskiego. Dane zaprezentowane na wykresie 2 zawierają znacznie bardziej niepokojące dane od tych zaprezentowanych na wykresie 1 . Okres spłaty zadłużenia gmin województwa kujawsko-pomorskiego wzrósł bowiem dużo bardziej niż stosunek zadłużenia do zrealizowanych dochodów. Żeby możliwe było wyciągnięcie dalej idących wniosków, w tabeli 1 zaprezentowano dane dotyczące okresu spłaty zadłużenia nadwyżką operacyjną, wyliczonego indywidualnie dla wszystkich gmin województwa kujawskopomorskiego w analizowanym okresie.

Tabela 1. Okres spłaty zadłużenia poszczególnych gmin województwa kujawskopomorskiego zrealizowanymi nadwyżkami operacyjnymi w latach 2002-2015.

\begin{tabular}{|c|c|c|c|c|c|c|c|c|c|c|c|c|c|c|}
\hline $\begin{array}{c}\text { Okres } \\
\text { splaty } \\
\text { (w latach) }\end{array}$ & $\mathbf{2 0 0 2}$ & $\mathbf{2 0 0 3}$ & $\mathbf{2 0 0 4}$ & $\mathbf{2 0 0 5}$ & $\mathbf{2 0 0 6}$ & $\mathbf{2 0 0 7}$ & $\mathbf{2 0 0 8}$ & $\mathbf{2 0 0 9}$ & $\mathbf{2 0 1 0}$ & $\mathbf{2 0 1 1}$ & $\mathbf{2 0 1 2}$ & $\mathbf{2 0 1 3}$ & $\mathbf{2 0 1 4}$ & $\mathbf{2 0 1 5}$ \\
\hline bez długu & 15 & 14 & 16 & 11 & 7 & 9 & 11 & 8 & 4 & 1 & 2 & 2 & 2 & 2 \\
\hline do 1 & 42 & 41 & 43 & 49 & 38 & 47 & 57 & 47 & 22 & 14 & 16 & 21 & 19 & 24 \\
\hline od 1 do 2 & 36 & 34 & 35 & 30 & 31 & 32 & 31 & 30 & 24 & 18 & 25 & 33 & 32 & 24 \\
\hline od 2 do 3 & 19 & 21 & 21 & 19 & 21 & 25 & 16 & 19 & 19 & 23 & 20 & 19 & 17 & 31 \\
\hline od 3 do 4 & 8 & 5 & 7 & 12 & 12 & 8 & 12 & 8 & 11 & 13 & 17 & 12 & 22 & 14 \\
\hline od 4 do 5 & 6 & 7 & 4 & 5 & 16 & 2 & 3 & 5 & 8 & 10 & 9 & 17 & 14 & 16 \\
\hline od 5 do 6 & 6 & 2 & 3 & 4 & 4 & 8 & 4 & 5 & 3 & 8 & 8 & 9 & 8 & 8 \\
\hline od 6 do 7 & 2 & 5 & 4 & 2 & 3 & 6 & 3 & 3 & 9 & 11 & 9 & 9 & 6 & 7 \\
\hline od 7 do 8 & 1 & 5 & 0 & 0 & 1 & 0 & 0 & 2 & 0 & 10 & 5 & 6 & 5 & 6 \\
\hline od 8 do 9 & 0 & 1 & 0 & 0 & 1 & 0 & 2 & 1 & 2 & 3 & 4 & 2 & 3 & 5 \\
\hline od 9 do 10 & 1 & 1 & 0 & 0 & 1 & 0 & 0 & 3 & 4 & 3 & 4 & 3 & 5 & 2 \\
\hline powyżej 10 & 7 & 5 & 7 & 4 & 8 & 4 & 3 & 7 & 21 & 26 & 22 & 10 & 10 & 4 \\
\hline $\begin{array}{c}\text { Nie jest } \\
\text { w stanie } \\
\text { spłacić }\end{array}$ & 1 & 3 & 4 & 8 & 1 & 3 & 2 & 6 & 17 & 4 & 3 & 1 & 1 & 1 \\
\hline Bydgoszcz & 5,7 & 11,3 & 5,3 & 3,0 & 3,6 & 3,0 & 5,0 & 10,1 & 63,7 & 14,2 & 13,7 & 11,7 & 9,9 & 7,9 \\
\hline Grudziądz & 10,0 & 4,4 & 1,9 & 4,9 & 5,0 & 4,5 & 3,6 & 6,7 & 9,7 & 7,8 & 10,7 & 9,9 & 7,5 & 13,1 \\
\hline Toruń & 10,8 & 10,1 & 5,9 & 4,1 & 4,0 & 2,8 & 3,6 & 5,4 & 9,6 & 16,5 & 11,7 & 9,8 & 11,5 & 9,8 \\
\hline Włocławek & 4,3 & 13,1 & 23,5 & 20,3 & 18,9 & 5,8 & 3,0 & 7,1 & 11,1 & 14,7 & 7,4 & 7,1 & 5,6 & 5,6 \\
\hline
\end{tabular}

Źródło: obliczenia własne na podstawie sprawozdań budżetowych badanych gmin. 
Wyjaśnienia wymaga pozycja przedstawiona w tabeli jako „Nie jest w stanie spłacić”. Dotyczy ona tych samorządów, które osiągnęły w danym roku budżetowym deficyt operacyjny, a więc zrealizowały wyższe wydatki bieżące, niż osiągnęły dochody bieżące. W takim przypadku spłata zobowiązań nie byłaby możliwa nawet w przypadku zupełnej rezygnacji z działalności inwestycyjnej. O tym, jakie wydatki i dochody mają charakter bieżących, decydują precyzyjne w tym zakresie zapisy klasyfikacji budżetowej. W tym miejscu wspomnieć trzeba o ważnej regule, która począwszy od 1 stycznia 2011 r. znacząco wpływa na gospodarkę finansową wszystkich polskich samorządów. Zgodnie z art. 242 u.f.p. organ stanowiący jednostki samorządu terytorialnego nie może uchwalić budżetu, w którym planowane wydatki bieżące są wyższe od planowanych dochodów bieżących powiększonych o nadwyżkę budżetową z lat ubiegłych i wolne środki stanowiące nadwyżkę środków pieniężnych na rachunku budżetu wynikającą z rozliczeń zaciągniętych wcześniej zobowiązań. Ponadto na koniec roku budżetowego wykonane wydatki bieżące nie mogą przekroczyć wykonanych dochodów bieżących powiększonych o nadwyżkę i wolne środki, o których mowa powyżej. Jedynym wyjątkiem od tej zasady są wydatki bieżące dokonywane z udziałem środków zagranicznej pomocy bezzwrotnej w przypadku, gdy nie zostały one przekazane w danym roku budżetowym. W swych zamierzeniach wymóg, nawiązujący do idei federalizmu fiskalnego, miał służyć zwiększeniu racjonalności gospodarki finansowej j.s.t. ${ }^{9}$

Z danych przedstawionych w tabeli 1 wynika kilka wniosków. Wnioskiem o charakterze ogólnym jest bardzo duża rozbieżność wskaźnika w ramach badanych gmin. Prawie wszystkie gminy województwa kujawsko-

9 Zamysł równoważenia części bieżącej budżetu został oceniony w literaturze przedmiotu pozytywnie, niemniej ze względu na pewną niekonsekwencję szczegółowe rozwiązania ustawowe zostały skrytykowane - zob. J.M. Salachna, Nowe formy prawne ograniczania deficytu oraz zadłużenia samorzqdu terytorialnego - próba oceny, [w:] J. Szołno-Koguc, A. Pomorska (red.), Ekonomiczne i prawne uwarunkowania i bariery redukcji deficytu i długu publicznego, Warszawa 2011, s. 521-530; R. Trykozko, Ustawa o finansach publicznych. Komentarz dla jednostek samorzqdu terytorialnego, Warszawa 2010, s. 428-429. 
pomorskiego korzystały w badanym okresie z zobowiązań o charakterze zwrotnym. Okresy spłaty dla lat 2002-2008 są, podobnie jak dane zaprezentowane na wykresach 1 i 2, dość stabilne. Zdecydowanie najwięcej gmin posiadało zadłużenie, które mogłyby one spłacić w stosunkowo krótkim okresie. W okresie od 2002 do 2009 r. okres spłaty poniżej 3 lat posiadało ponad 2/3 zbadanych gmin. Sytuacja diametralnie zmieniła się w 2010 r., kiedy to taki okres spłaty posiadała mniej niż połowa gmin, a aż 17 gmin odnotowało ujemne wyniki operacyjne, co przy utrzymaniu się podobnych tendencji w latach kolejnych spowodowałoby, że nigdy nie byłyby one w stanie spłacić swego zadłużenia, do tego 21 gmin musiałoby spłacać swoje zadłużenie dłużej niż 10 lat. Pozwala to sformułować wniosek, że w 2010 r. znacząco zmniejszyło się bezpieczeństwo finansowe gmin województwa kujawsko-pomorskiego. Sytuacja w latach kolejnych ulegała poprawie, niemniej w 2011 r. aż 26 gmin posiadało ponad dziesięcioletni okres spłaty posiadanego zadłużenia, a w kolejnym, 2012 r., były to wciąż 22 gminy. Znacząca poprawa bezpieczeństwa finansowego gmin województwa kujawsko-pomorskiego nastąpiła zaś dopiero w 2013 r.

Oprócz dużej rozbieżności okresu spłaty w gminach województwa kujawsko-pomorskiego kolejnym wnioskiem natury ogólnej jest dynamiczna zmiana wyników w czasie, dużo bardziej dynamiczna niż stosunek zadłużenia do zrealizowanych dochodów. W tym kontekście warto zwrócić uwagę na fakt, że począwszy od 2014 r. obowiązują nowe limity ilościowe zadłużenia samorządowego. Każda jednostka samorządu terytorialnego posiada obliczony na podstawie danych historycznych z poprzednich 3 lat indywidualny wskaźnik zadłużenia (dalej IWZ), o wysokości którego decyduje w największym stopniu poziom generowanych nadwyżek operacyjnych. IWZ został zaimplementowany do obowiązującego stanu prawnego na mocy zapisów u.f.p. Sam zamysł zmian limitowania zadłużenia j.s.t. został pozytywnie oceniony przez środowisko naukowe, szczegółowe rozwiązania spotkały się jednak z silną krytyką. Według M. Jastrzębskiej rozwiązania nadal nie uwzględniają specyfiki po- 
szczególnych szczebli samorządu ${ }^{10}$; B. Filipiak krytykowała okres, na podstawie którego wyznacza się IWZ, oraz fakt oparcia wskaźnika jedynie w oparciu o dane historyczne ${ }^{11}$; M. Wiśniewski wskazywał na niedostosowanie do zmian koniunkturalnych ${ }^{12}$. Literatura przedmiotu zawiera oczywiście również inne krytyczne uwagi. Warto jednakże zwrócić uwagę, że w przypadku gmin województwa kujawsko-pomorskiego ich bezpieczeństwo finansowe uległo znacznemu pogorszeniu w okresie nowelizowania ustawy o finansach publicznych, ale już po trzech latach po wprowadzeniu IWZ sytuacja uległa wyraźnemu ustabilizowaniu. W opinii autora ogromne znaczenie miało właśnie wprowadzenie rozwiązań uzależniających możliwości zadłużania się właśnie od nadwyżki operacyjnej samorządów. Mając zaś na uwadze to decydujące znaczenie nadwyżki operacyjnej dla możliwości zadłużania się samorządów, wydaje się, że obecnie zdecydowanie lepszym miernikiem tego zadłużenia jest prezentowany w niniejszym tekście okres spłaty nadwyżką operacyjną. W tym kontekście znaczna zmienność okresu w czasie nie stanowi wady uwzględniając fakt, że mocno zmienna okazuje się sama kondycja finansowa samorządów.

Wyjaśnienia wymaga jeszcze kwestia przyczyn, dla których dane przedstawione dla poszczególnych gmin wyraźnie odbiegają od sytuacji ogółu gmin przedstawionego na wykresie 2. Decydujące znaczenie ma zadłużenie miast na prawach powiatu województwa kujawsko-pomorskiego. Posiadają one zdecydowaną większość zadłużenia zbadanych gmin, którego spłata wymagać będzie przynajmniej kilku, a nawet kilkunastu lat przy założeniach dalszego niezwiększania zadłużenia oraz drastycznego ograniczenia działalności inwestycyjnej. Kolejna perspektywa budżetu Unii Europejskiej powoduje, że obydwa te założenia uznać

10 M. Jastrzębska, Ograniczenia zadłużenia jednostek samorzqdu terytorialnego $w$ świetle spełniania przez Polskę kryteriów fiskalnych konwergencji, „Finanse Komunalne” 2009, nr 4, s. 23.

11 B. Filipiak, Samorzqdowy dług publiczny w Polsce w perspektywie zmian ustrojowych, [w:] L. Patrzałek (red.), Finanse - nowe wyzwania teorii i praktyki. Finanse publiczne, 2011, s. 533.

12 M. Wiśniewski, Dług samorzq̨dowy i jego limity w świetle wieloletnich prognoz finansowych jednostek samorzqdu terytorialnego w Polsce, „Finanse Komunalne” 2014, nr 4, s. 24. 
trzeba za całkowicie nierealne. Długość okresu spłaty wszystkich miast na prawach województwa kujawsko-pomorskiego (a więc Bydgoszczy, Grudziądza, Torunia oraz Włocławka - kolejność alfabetyczna) przedstawiona została w tabeli 1.

Autor przeprowadził jeszcze jedną analizę. Na podstawie projektów uchwał gmin województwa kujawsko-pomorskiego w sprawie wieloletnich prognoza finansowych złożonych wraz z projektami uchwał budżetowych na lata 2011-2015 określono długość prognoz kwoty długu, będących obligatoryjną częścią tych uchwał. Dane okazały się w tym zakresie zaskakująco stabilne. Średni okres prognoz spłaty długu ${ }^{13}$ wyniósł bowiem: 10,1 lat w 2011 r.; 10,9 lat w 2012 r.; 11,2 lat w 2013 r.; 10,7 lat w 2014 r. oraz 10,3 lat w 2015 r. Konfrontując te dane z danymi finansowymi wynikającymi z przeprowadzonych i zaprezentowanych wcześniej badań, stwierdzić należy, że okresy spłaty zadłużenia samorządowego zawarte w wieloletnich prognozach finansowych samorządów nie wydają się być wiarygodnym źródłem informacji, na podstawie których wyciągać można daleko idące wnioski.

\section{Podsumowanie}

Proces kreowania rozwoju lokalnego wydaje się być praktycznie niemożliwy bez wykorzystania zwrotnych źródeł finansowania. Nie wszystkie zobowiązania zwrotne są jednakże nośnikiem wyłącznie pozytywnych zmian, a występowanie negatywnych zjawisk związanych ze wzrostem zadłużenia stało się szczególnie wyraźne od 2010 r.

Analiza zadłużenia publicznego, w szczególności związanego z jednostkami samorządu terytorialnego, musi być prowadzona ze świadomością, że znaczna część zobowiązań podmiotów publicznych o charakterze zwrotnym znajduje się poza statystyką publiczną. Dotyczy to chociażby zadłużenia komunalnych spółek prawa handlowego ${ }^{14}$ oraz szpitali ${ }^{15}$.

13 Zgodnie $\mathrm{z}$ art. 227 ustawy o finansach publicznych prognozę należy sporządzić na okres, na który zaciągnięto oraz planuje się zaciągnąć zobowiązania.

14 Więcej na temat zadłużenia spółek komunalnych zob. A. Borodo, Głos w sprawie zakresu długu oraz deficytu jednostki samorzqdu terytorialnego, „Finanse Komunalne” 
Ze względu na ograniczony rozmiaru publikacji oraz cele, jakim służy, dalsze rozważania w tym zakresie nie są jednakże możliwe.

Nieuwzględnianie wszystkich negatywnych aspektów związanych z zadłużeniem samorządowym oraz zbyt optymistyczne przewidywania dotyczące efektów realizowanych z tych środków przedsięwzięć inwestycyjnych mogą spowodować, że samorządowy dług publiczny stanie się istotną barierą ograniczającą procesy rozwojowe w najbliższych latach.

Niniejszy tekst nie może oczywiście aspirować do miana kompleksowego rozwiązania pojawiających się wątpliwości. Pomimo to autor ma nadzieję, że tekst może stanowić inspirację dla licznych badaczy zagadnień związanych z finansami publicznymi, w tym w szczególności z zadłużeniem publicznym.

\section{Bibliografia:}

Bitner M., Spółki prawa handlowego - przeniesienie zadłużenia poza JST, [w:] P. Walczak (red.), Zadłużenie jednostek samorzqdu terytorialnego, Wydawnictwo C.H. Beck, Warszawa 2014, s. 235-260.

Borodo A., Kredyty, pożyczki i obligacje jako źródło finansowania zadań jednostek samorzqdu terytorialnego [w:] A. Borodo (red.), Samorzq̨d terytorialny a banki, Dom Organizatora TNOiK, Toruń 2002, s. 7-37.

Borodo A., Głos w sprawie zakresu długu i deficytu jednostki samorzqdu terytorialnego, „Finanse Komunalne” 2012, nr 1-2, s. 52-57.

Cichocki K.S., Zarzqdzanie finansami i długiem samorzqdu terytorialnego w perspektywie wieloletniej, Polska Akademia Nauk, Instytut Badań Naukowych, Warszawa 2013.

Czempas J., Skłonność jednostek samorzq̨du terytorialnego do inwestowania. Ujęcie ilościowe na przykładzie miast na prawach powiatu województwa ślq̨skiego, Wydawnictwo Uniwersytetu Ekonomicznego w Katowicach, Katowice 2013.

2012, nr 1-2, s. 52-57; M. Bitner, Spółki prawa handlowego - przeniesienie zadłużenia poza JST, [w:] P. Walczak (red.), Zadłużenie jednostek samorzq̨du terytorialnego, Warszawa 2014, s. 235-260.

15 W przypadku gmin województwa kujawsko-pomorskiego szczególnie dotyczy to Regionalnego Szpitala Specjalistycznego w Grudziądzu, którego zadłużenie znacząco przekracza zadłużenie miasta Grudziądz, będącego jego organem tworzącym. 
Filipiak B., Samorzqdowy dług publiczny w Polsce w perspektywie zmian ustrojowych, [w:] L. Patrzałek (red.), Finanse - nowe wyzwania teorii i praktyki. Finanse publiczne, Wydawnictwo Uniwersytetu Ekonomicznego we Wrocławiu, Wrocław 2011, s. 525-535.

Jastrzębska M., Ograniczenia zadłużenia jednostek samorzq̨du terytorialnego w świetle spełniania przez Polskę kryteriów fiskalnych konwergencji, „Finanse Komunalne” 2009, nr 4, s. 13-30.

Jurewicz D., Dług samorzq̨du - bodziec czy bariera absorpcji środków europejskich?, „Ruch Prawniczy, Ekonomiczny i Socjologiczny” 2016, nr 2, s. 231-249.

Jurewicz D., Refinansowanie długu polskich gmin, tekst w druku, planowany do opublikowania w: „Ruch Prawniczy, Ekonomiczny i Socjologiczny” 2017, nr 2.

Poniatowicz M., Dług publiczny w systemie finansowym jednostek samorzqdu terytorialnego (na przykładzie miast na prawach powiatu), Wydawnictwo Uniwersytetu w Białymstoku, Białystok 2005.

Poniatowicz M., Dobry dług versus zły dług, czyli o specyfice zadłużenia sektora samorzqdowego, [w:] J. Szołno-Koguc, A. Pomorska (red.), Ekonomiczne i prawne uwarunkowania i bariery redukcji deficytu i długu publicznego, Wolters Kluwer business, Warszawa 2011, s. 488-500.

Poniatowicz M., Salachna J.M., Perło D., Efektywne zarzq̨dzanie długiem w jednostce samorzqdu terytorialnego, Oficyna Wolters Kluwer business, Warszawa 2010.

Salachna J.M., Nowe formy prawne ograniczania deficytu oraz zadłużenia samorzq̨du terytorialnego - próba oceny, [w:] J. Szołno-Koguc, A. Pomorska (red.), Ekonomiczne i prawne uwarunkowania i bariery redukcji deficytu i długu publicznego, Wolters Kluwer business, Warszawa 2011, s. 521-530.

Trykozko R., Ustawa o finansach publicznych. Komentarz dla jednostek samorzq̨du terytorialnego, Taxpress, Warszawa 2010.

Uryszek T., Ryzyko refinansowania długu Skarbu Państwa w Polsce, „Finanse i Prawo Finansowe” 2014, nr 2, s. 55-57.

Wiśniewski M., Dług samorzq̨dowy i jego limity w świetle wieloletnich prognoz finansowych jednostek samorzqdu terytorialnego w Polsce, „Finanse Komunalne” 2014, nr 4, s. 20-29.

Zioło M., Zadłużenie gmin - przesłanka czy ograniczenie w procesie kreowania ich rozwoju? Analiza przypadku na przykładzie gmin województwa zachodniopomorskiego, [w:] J. Szołno-Koguc, A. Pomorska (red.), Ekonomiczne i prawne uwarunkowania i bariery redukcji deficytu i długu publicznego, Wolters Kluwer business, Warszawa 2011, s. 473-487. 